\title{
Co-disposal of lignite fly ash and coal mine waste rock for neutralisation of AMD
}

\author{
Asif Qureshi $^{1,2}$ (D) Christian Maurice ${ }^{1} \cdot$ Björn Öhlander ${ }^{1}$
}

Received: 11 July 2020 / Accepted: 14 March 2021 / Published online: 29 April 2021

(C) The Author(s) 2021

\begin{abstract}
Waste rocks (WRs) from a lignite-producing coalfield and fly ash (FA) produced from the same lignite have been investigated in this study with a primary objective to determine the potential for co-disposal of WRs and FA to reduce the environmental contamination. Mixing WRs with FA and covering WRs with FA have been investigated. Particle size effect caused $\leq 2 \mathrm{~mm}$ particles to produce low $\mathrm{pH}(\sim 2)$ and metal-laden leachates, indicating higher sulphide minerals' reactivity compared to larger particles $(\leq 10 \mathrm{~mm}, \mathrm{pH} \sim 4)$. Co-disposal of FA as mixture showed an instantaneous effect, resulting in higher $\mathrm{pH}(\sim 3-6)$ and better leachate quality. However, acidity produced by secondary mineralisation caused stabilisation of $\mathrm{pH}$ at around $4.5-5$. In contrast, the $\mathrm{pH}$ of the leachates from the cover method gradually increased from strongly acidic $(\mathrm{pH} \sim 2)$ to mildly acidic $(\mathrm{pH} \sim$ 4-5) and circumneutral $(\mathrm{pH} \sim 7)$ along with a decrease in EC and elemental leaching. Gradually increasing $\mathrm{pH}$ can be attributed to the cover effect, which reduces the oxygen diffusion, thus sulphide oxidation. FA cover achieved the $\mathrm{pH}$ necessary for secondary mineralisation during the leaching experiment. The co-disposal of FA as cover and/or mixture possesses the potential for neutralisation and/or slowing down AMD and improving leachate quality.
\end{abstract}

Keywords Coal mine waste rock $\cdot$ Acid mine drainage $\cdot$ Fly ash $\cdot$ Co-disposal $\cdot$ Remediation $\cdot$ Prevention

\section{Introduction}

Despite the latest developments towards cleaner alternative fuels, coal still makes up to about $15.9 \%$ share in the total global primary energy supply (IEA 2019a). Worldwide coal production increased by $250 \mathrm{Mt}$ ( $\sim 3.3 \%$ compared to 2017$)$ with a total of $\sim 7.81 \mathrm{Bt}$ in 2018 (IEA 2019b). However, coal mining raises particularly significant environmental concerns. Apart from the carbon dioxide effect, it produces waste rocks (WRs) that often contain sulphides, with principally high contents of iron sulphides such as pyrite $\left(\mathrm{FeS}_{2}\right)$ and pyrrhotite

Responsible Editor: Philippe Garrigues

Asif Qureshi

qureshi.asif@outlook.com

1 Department of Civil, Environmental and Natural Resources Engineering, Division of Geosciences and Environmental Engineering, Luleå University of Technology, SE-97187 Luleå, Sweden

2 Department of Energy and Environment Engineering, Quaid-e-Awam University of Engineering, Science and Technology, Nawabshah 67480, Pakistan
$\left(\mathrm{Fe}_{1-\mathrm{x}} \mathrm{S}\right)$. High concentrations of trace elements such as As, $\mathrm{Cu}, \mathrm{Hg}, \mathrm{Zn}, \mathrm{Ni}, \mathrm{Co}, \mathrm{Mo}, \mathrm{Se}$, and $\mathrm{Cr}$ are also often present in WRs.

The sulphide-rich WRs are considered environmentally damaging because the sulphide minerals are unstable when exposed to the surface atmospheric conditions. The sulphide minerals, in presence of water and oxygen, produce acidic leachates with increased concentrations of major and trace elements that eventually end up in natural water resources. Such a process is commonly referred to as acid mine drainage (AMD). For instance, results from Qureshi et al. (2016a) showed that the WRs from a lignite-producing coal field in Pakistan had strong AMD potential and could seriously affect the quality of the surrounding environment.

Therefore, there are many methods that have been developed to treat and/or mitigate AMD from mining wastes in the last few decades such as in-pit disposal, wet and dry covers, and blending and co-disposal ( $\mathrm{Li}$ et al. 2011; Villain et al. 2013; Nason et al. 2013; Mäkitalo et al. 2015; Kalonji Kabambi et al. 2017; Pouliot et al. 2018; Jia et al. 2019). The prevention (minimisation) techniques for AMD aim to stop sulphide oxidation and migration of weathering products to the environment by minimising the reaction rates and 
elemental leaching (INAP 2014). The basic concept behind most of the prevention techniques is to reduce and/or stop oxygen diffusion and water infiltration through the waste deposits.

Although selection of prevention/mitigation methods can be site-specific, in-pit disposal, mixing and blending, co-disposal, and wet and dry covers are the most commonly used methods today. For instance, wet and dry covers have been studied by Boulanger-Martel et al. (2017), Höglund et al. (2004) and Lessard et al. (2018).

On the other hand, utilisation of coal for heat and power generates fly ash (FA) that contains ecologically harmful substances (including $\mathrm{As}, \mathrm{B}, \mathrm{Cd}, \mathrm{Cr}, \mathrm{Cu}, \mathrm{Pb}, \mathrm{Se}$ and $\mathrm{Zn}$ ) (Martinello et al. 2014; Yao et al. 2015). Despite this, FA has been utilised in different ways such as in concrete/ concrete products, blended cement, road base/sub-base and soil modification/stabilisation (Shanmugan et al. 2020; Gupta et al. 2020; Cavusoglu et al. 2021), thanks to its physical (self-hardening) properties. Moreover, in recent years, several studies have shown that FA and its composites are effective in the neutralisation of AMD (Gitari et al. 2006; Pérez-López et al. 2007, 2009; Prasad and Mortimer 2011; Bäckström and Sartz 2011; Jia et al. 2014; Jouini et al. 2020). Therefore, FA, due to its acid-neutralising and physical properties, can be used as a dry cover material over WR dumps to isolate them from the surface atmospheric conditions and prevent AMD generation, or it can be mixed with WRs to backfill underground coal mines and prevent or neutralise any AMD that might be generated by the WRs. Notwithstanding, it is important to study both materials on a laboratory scale before any full-scale application to determine the best practice to be adopted in the field to remediate the waste materials.

Therefore, WRs from one of the largest lignite-producing coal fields in Pakistan and FA from a coal-fired power station that incinerates coal from the same field were studied in this research. The physicochemical behaviour of the WRs and FA has been reported in our previous studies (Qureshi et al. 2016a, b). Furthermore, effects of co-disposing these WRs and FA have also been reported in Qureshi et al. (2019) whereby $70 \mathrm{~g}$ of very fine grained crushed WRs $(\leq 1 \mathrm{~mm})$ were mixed in three different FA:WR ratios $(1: 1,1: 3$ and 1:5) to perform weathering cell experiments. Although the acidity was not completely neutralised during the experiments, the results indicated that 1:1 ratio performed very well in improving $\mathrm{pH}$ and leachate quality. This is interesting because the approximate ratio of WR to FA production tends to be $1: 1$ from the Lakhra coal field and the power station. Therefore, the objectives of this study were to (i) evaluate the impact of particle size on AMD generation and leachate quality, (ii) determine the effectiveness of co-disposal (mixing and cover) of lignite FA for AMD neutralisation and (iii) identify the potential for precipitation/co-precipitation and/or dissolution of the secondary minerals to take place in both cases using a thermodynamic geochemical model (PHREEQC).

\section{Materials and methods}

\section{Materials}

\section{Waste rocks}

The samples of WRs were collected from four deposits near three underground coal mines in one of the largest coal fields (Lakhra) in Pakistan. The estimated coal reserves in the field are approximately $1.3 \mathrm{Bt}$ with qualities varying from lignite to sub-bituminous (LCDC 2020). The WR samples were selected based on previously determined acid-generating potential (Qureshi et al. 2016a). The details of the WR samples are shown in Table 1.

\section{Fly ash}

The FA was generated from a fluidised bed combustion (FBC) power station which burns lignite coal with some addition of limestone. The FA sample was collected from the filter bag house.

\section{Methods}

\section{Mineralogy and chemical composition}

A detailed mineralogical and chemical characterisation of WRs and FAs has been described in our previous work (Qureshi et al. 2016a, b) and is summarised in Table 2 and Table 3, respectively.

Briefly, the mineralogy was determined using XRD and SEM; the chemical characterisation was achieved by analysing the samples using ICP-MS and ICP-AES following the methods described in the "Physicochemical characterisation of eluates" section below.

\section{Column leaching experiment}

Columns were prepared from plexiglas tubes, each of $25 \mathrm{~cm}$ in height, $5 \mathrm{~cm}$ diameter and sealed with a rubber qwick cap at bottom. A nylon filter of $1 \mu \mathrm{m}$ was placed and small nipple was installed at the bottom to filter and extract leachate, respectively. Sample material was filled and naturally compacted to a maximum height of approximately $15 \mathrm{~cm}$.

Because this study also focuses on the effect of particle size on leaching, and due to the fact that our previous studies used very fine grain size of WRs $(\leq 1 \mathrm{~mm})$ for weathering cell experiments, the column leaching experiment (CLE) were performed on three different particle sizes of WRs $(\leq 2 \mathrm{~mm}$, 
Table 1 Details of the WR samples

\begin{tabular}{llll}
\hline Sample designation & Sample location & Characteristics & Acid-generating potential (NNP) \\
\hline WR1 & Mine 1 & Two to 3 months old & $-144 \pm 112 \mathrm{CaCO}_{3}$ tonne \\
WR2 & Mine 1 & Less than a week old & $-70 \pm 6 \mathrm{CaCO}_{3}$ tonne \\
WR3 & Mine 3 & Less than a week old & $-492 \pm 178 \mathrm{CaCO}_{3}$ tonne $^{-1}$ \\
\hline
\end{tabular}

${ }^{\mathrm{a}}$ After Qureshi et al. (2016a)

${ }^{\mathrm{b}}$ WR from mine 2 was excluded here due to the similar behaviour as WR3 $\leq 5 \mathrm{~mm}$ and $\leq 10 \mathrm{~mm}$ ). The weight of material was $230 \mathrm{~g}$ of WR1, $265 \mathrm{~g}$ of WR2 and $278 \mathrm{~g}$ of WR3 in each column. FA cover and mixture scenarios were mimicked by making two separate columns with $\leq 10 \mathrm{~mm}$ particle size of WR sample, one with a small FA cover on top of the sample and one with mixing FA and WR. The proportion of FA (FA:WR) was 1:5 in the cover scenario and 1:3 in the mixture scenario. The ratios were inspired from our previous study (Qureshi et al. 2019). A total of five columns for each WR type were tested. An illustration of the experimental setup is shown in in Fig. 1.

Leaching was performed for 92 days (five rinses) with varying leaching times (1-4 days) and 10 drying days in between each rinse. Different liquid-to-solid (L/S) ratios $(1,5,10$ and $15 \mathrm{~L} \mathrm{~kg}^{-1}$ ) were used for each rinse, and, after the 4 th rinse, the $\mathrm{L} / \mathrm{S}$ ratio 1 was applied again to evaluate any effect of $\mathrm{L} / \mathrm{S}$ ratio on differences in physicochemical composition of leachates. MilliQ ${ }^{\mathrm{TM}}$ water was used as leaching solution and a peristatic pump was used to control the flow rate and duration of each rinse.

Immediately after completion of each rinse, the eluates were filtered with a $0.45 \mu \mathrm{m}$ nylon filter and the $\mathrm{pH}$, redox potential (Eh) and electrical conductivity (EC) of each eluate were determined. The eluates were then placed in a laboratory freezer at a temperature below $-18{ }^{\circ} \mathrm{C}$ before their chemical analyses. However, the effect of particle size on elemental leaching was only analysed for WR 1. Since $\mathrm{pH}$ (Lottermoser 2007) and EC (Gray 1996a) can be good indicators of sulphide oxidation (AMD), they were used as indicators of AMD in WR2 and WR3.

\section{Physicochemical characterisation of eluates}

The proportions of 29 major elements ( $\mathrm{Si}, \mathrm{Al}, \mathrm{Ca}, \mathrm{Fe}, \mathrm{K}, \mathrm{Mg}$, $\mathrm{Mn}, \mathrm{Na}, \mathrm{P}, \mathrm{Ti}$ ) and trace elements (As, $\mathrm{Ba}, \mathrm{Be}, \mathrm{Cd}, \mathrm{Co}, \mathrm{Cr}, \mathrm{Cu}$, $\mathrm{Hg}, \mathrm{Nb}, \mathrm{Ni}, \mathrm{Pb}, \mathrm{S}, \mathrm{Sc}, \mathrm{Sr}, \mathrm{V}, \mathrm{W}, \mathrm{Y}, \mathrm{Zn}, \mathrm{Zr}$ ) in the WRs and eluates were determined using inductively coupled plasmaatomic emission spectrometry (ICP-AES (Martin et al. 1991)) and inductively coupled plasma-mass spectrometry (ICP-MS (Long and Martin 1991)) at a SWEDACaccredited laboratory (ALS Scandinavia, Luleå, Sweden).

The ICP-AES analyses were carried out using a Perkin Elmer Optima DV 5300 instrument following US EPA Method 200.7 (modified). The ICP-MS analyses were carried out using a Thermo-Scientific Element instrument following US EPA Method 200.8 (modified). Briefly, the samples were digested with $\mathrm{HNO}_{3}$ and analysed for $\mathrm{As}, \mathrm{Cd}, \mathrm{Co}, \mathrm{Cu}, \mathrm{Hg}, \mathrm{Ni}$, $\mathrm{Pb}, \mathrm{S}$ and $\mathrm{Zn}$. All other elements were analysed after fusion with lithium methaborate $\left(\mathrm{LiBO}_{2}\right)$ and subsequent dissolution in $\mathrm{HNO}_{3}$.

Additionally, modified versions of procedures CSN EN ISO 10304-1 and CSN EN ISO 10304-2 for $\mathrm{Cl}, \mathrm{F}$ and $\mathrm{SO}_{4}{ }^{2-}$ and CSN EN 1484 for DOC were carried out by the same laboratory.
Table 2 Mineralogy of the samples determined by XRD

\begin{tabular}{|c|c|}
\hline Sample & Mineralogy \\
\hline $\mathrm{FA}^{\mathrm{a}}$ & $\begin{array}{l}\text { Iron (III) oxide }\left(\mathrm{Fe}_{2} \mathrm{O}_{3}\right) \text {, quartz }\left(\mathrm{SiO}_{2}\right) \text {, anhydrite }\left(\mathrm{CaSO}_{4}\right) \text { and magnesioferrite }\left(\mathrm{Mg}\left(\mathrm{Fe}^{3+}\right)_{2} \mathrm{P}_{4}\right) \text {, } \\
\quad \text { quiklime* }(\mathrm{CaO})\end{array}$ \\
\hline $\mathrm{WR} 1^{\mathrm{b}}$ & $\begin{array}{l}\text { Dominated by quartz }\left(\mathrm{SiO}_{2}\right) \text {, arsenopyrite }(\mathrm{FeAsS}) \text { and kaolinite }\left(\mathrm{Al}_{2} \mathrm{Si}_{2} \mathrm{O}_{5}(\mathrm{OH})_{4}\right) \text {, with variable } \\
\text { amounts of pyrite }\left(\mathrm{FeS}_{2}\right) \text {, calcite }\left(\mathrm{CaCO}_{3}\right) \text { ad gypsum }\left(\mathrm{CaSO}_{4} 2 \mathrm{H}_{2} \mathrm{O}\right)\end{array}$ \\
\hline $\mathrm{WR} 2^{\mathrm{b}}$ & $\begin{array}{l}\text { Dominated by pyrite* }\left(\mathrm{FeS}_{2}\right) \text {, kaolinite }\left(\mathrm{Al}_{2} \mathrm{Si}_{2} \mathrm{O}_{5}(\mathrm{OH})_{4}\right) \text {, haematite }\left(\mathrm{Fe}_{2} \mathrm{O} 3\right) \text { and gypsum } \\
\quad\left(\mathrm{CaSO}_{4} \cdot 2 \mathrm{H}_{2} \mathrm{O}\right) \text {, with variable amounts of quartz }\left(\mathrm{SiO}_{2}\right)\end{array}$ \\
\hline $\mathrm{WR}^{\mathrm{b}}{ }^{\mathrm{b}}$ & $\begin{array}{l}\text { Dominated by pyrite }\left(\mathrm{FeS}_{2}\right) \text {, quartz }(\mathrm{SiO} 2) \text { and kaolinite }\left(\mathrm{Al} 2 \mathrm{Si} 2 \mathrm{O} 5(\mathrm{OH})_{4}\right) \text {, with variable amounts of } \\
\text { malladerite }\left(\mathrm{Na}_{2} \mathrm{SiF}_{6}\right) \text {, spangolite }\left(\mathrm{Cu} 6 \mathrm{Al}\left(\mathrm{SO}_{4}\right)(\mathrm{OH})_{12} \mathrm{Cl} \cdot 3\left(\mathrm{H}_{2} \mathrm{O}\right)\right) \text {, franklinite }\left(\mathrm{ZnFe}_{2} \mathrm{O}_{4}\right)\end{array}$ \\
\hline
\end{tabular}

\footnotetext{
${ }^{a}$ After Qureshi et al. (2016b)

${ }^{\mathrm{b}}$ After Qureshi et al. (2016a)

*Fresh analysis
} 
Table 3 Major and trace element composition of the samples as determined by ICP-MS and ICPAES analyses

\begin{tabular}{|c|c|c|c|c|c|}
\hline Element & $\mathrm{FA}^{\mathrm{a}, \mathrm{b}}$ & $\mathrm{WR} 1^{\mathrm{a}, \mathrm{c}}$ & $\mathrm{WR} 2^{\mathrm{a}, \mathrm{c}}$ & WR $3^{a, c}$ & $\mathrm{CC}^{\mathrm{d}}$ \\
\hline Dry weight (\%) & $98.7 \pm 0.1$ & $90.53 \pm 5.38$ & $77.33 \pm 0.12$ & $83.93 \pm 0.23$ & n.d \\
\hline $\mathrm{Si}(\% \mathrm{dw})$ & $12.43 \pm 0.42$ & $8.33 \pm 5.79$ & $11.14 \pm 2.04$ & $9.54 \pm 3.97$ & 27.72 \\
\hline $\mathrm{Al}(\% \mathrm{dw})$ & $9.47 \pm 0.37$ & $6.84 \pm 4.7$ & $9.24 \pm 1.72$ & $6.26 \pm 2.35$ & 8.13 \\
\hline $\mathrm{Ca}(\% \mathrm{dw})$ & $3.92 \pm 0.14$ & $3.69 \pm 5.64$ & $0.44 \pm 0.1$ & $0.36 \pm 0.06$ & 3.63 \\
\hline $\mathrm{Fe}(\% \mathrm{dw})$ & $24.25 \pm 1.55$ & $3.9 \pm 4.26$ & $1.57 \pm 0.42$ & $10.07 \pm 3.88$ & 5 \\
\hline $\mathrm{K}(\% \mathrm{dw})$ & $0.42 \pm 0.01$ & $0.4 \pm 0.25$ & $0.41 \pm 0.11$ & $0.33 \pm 0.16$ & 2.59 \\
\hline $\operatorname{Mg}(\% \mathrm{dw})$ & $1.22 \pm 0.6$ & $0.51 \pm 0.09$ & $0.54 \pm 0.01$ & $0.28 \pm 0.04$ & 2.09 \\
\hline $\mathrm{Mn}(\% \mathrm{dw})$ & $0.05 \pm 0$ & $0.05 \pm 0.07$ & $0 \pm 0$ & $0.01 \pm 0$ & 0.095 \\
\hline $\mathrm{Na}(\% \mathrm{dw})$ & $1.19 \pm 0.03$ & $0.16 \pm 0.09$ & $0.21 \pm 0.04$ & $0.21 \pm 0.02$ & 2.83 \\
\hline $\mathrm{P}(\% \mathrm{dw})$ & $0.03 \pm 0$ & $0.02 \pm 0.01$ & $0.02 \pm 0$ & $0.02 \pm 0.01$ & 0.11 \\
\hline $\mathrm{Ti}(\% \mathrm{dw})$ & $1.11 \pm 0.06$ & $0.41 \pm 0.31$ & $0.57 \pm 0.13$ & $0.69 \pm 0.34$ & 0.44 \\
\hline LOI (\% dw) & $7.93 \pm 0.1$ & n.d & n.d & n.d & n.d \\
\hline $\mathrm{S}(\% \mathrm{dw})$ & $2.40 \pm 0.20$ & $10.7 \pm 12$ & $1.90 \pm 0.15$ & $11.30 \pm 4.70$ & 0.02 \\
\hline As (mg/kg dw) & $7.49 \pm 0.6$ & $8.15 \pm 8.13$ & $0.3 \pm 0.08$ & $3.88 \pm 0.73$ & 1.8 \\
\hline $\mathrm{Ba}(\mathrm{mg} / \mathrm{kg} \mathrm{dw})$ & $211 \pm 8$ & $98.53 \pm 61.46$ & $123 \pm 22$ & $83.33 \pm 36.15$ & 425 \\
\hline $\mathrm{Be}(\mathrm{mg} / \mathrm{kg} \mathrm{dw})$ & $7.25 \pm 0.4$ & $2.3 \pm 1.48$ & $3.48 \pm 0.42$ & $1.84 \pm 0.32$ & 2.8 \\
\hline $\mathrm{Cd}(\mathrm{mg} / \mathrm{kg} \mathrm{dw})$ & $0.97 \pm 0.1$ & $0.3 \pm 0.04$ & $0.22 \pm 0.07$ & $0.25 \pm 0.12$ & 0.2 \\
\hline $\mathrm{Co}(\mathrm{mg} / \mathrm{kg} \mathrm{dw})$ & $88.6 \pm 8$ & $40.23 \pm 26.07$ & $15.43 \pm 4.55$ & $43.5 \pm 21.88$ & 25 \\
\hline $\mathrm{Cr}(\mathrm{mg} / \mathrm{kg} \mathrm{dw})$ & $168 \pm 7$ & $67.63 \pm 52.6$ & $111 \pm 20$ & $101 \pm 37$ & 100 \\
\hline $\mathrm{Cu}(\mathrm{mg} / \mathrm{kg} \mathrm{dw})$ & $119 \pm 12$ & $73.43 \pm 53.26$ & $101 \pm 30$ & $24.97 \pm 2.04$ & 55 \\
\hline $\mathrm{Hg}(\mathrm{mg} / \mathrm{kg} \mathrm{dw})$ & $0.49 \pm 0.1$ & $0.22 \pm 0.07$ & $0.14 \pm 0.02$ & $0.1 \pm 0.02$ & 0.08 \\
\hline Ni (mg/kg dw) & $155 \pm 15$ & $87.83 \pm 38.94$ & $50.27 \pm 14.26$ & $61.1 \pm 30.57$ & 75 \\
\hline $\mathrm{Pb}(\mathrm{mg} / \mathrm{kg} \mathrm{dw})$ & $18.9 \pm 2$ & $14.54 \pm 9.14$ & $20.27 \pm 5.02$ & $8.88 \pm 3.57$ & 13 \\
\hline $\mathrm{Sr}(\mathrm{mg} / \mathrm{kg} \mathrm{dw})$ & $1510 \pm 61$ & $302 \pm 103$ & $241 \pm 10$ & $126 \pm 18$ & 375 \\
\hline $\mathrm{V}(\mathrm{mg} / \mathrm{kg} \mathrm{dw})$ & $339 \pm 7$ & $178 \pm 139$ & $256 \pm 38$ & $139 \pm 47$ & 135 \\
\hline $\mathrm{Zn}(\mathrm{mg} / \mathrm{kg} \mathrm{dw})$ & $218 \pm 24$ & $70.6 \pm 7.6$ & $50.1 \pm 3.9$ & $49.67 \pm 15.15$ & 70 \\
\hline $\mathrm{Zr}(\mathrm{mg} / \mathrm{kg} \mathrm{dw})$ & $277 \pm 5$ & $75.03 \pm 56.56$ & $119.7 \pm 22$ & $135 \pm 50$ & 165 \\
\hline
\end{tabular}

$d w$ dry weight, $n . d$ not determined, $n / a$ not applicable

${ }^{\mathrm{a}}$ Mean \pm standard deviation $(n=3)$

${ }^{\mathrm{b}}$ After Qureshi et al. (2016b)

${ }^{\mathrm{c}}$ After Qureshi et al. (2016a)

${ }^{\mathrm{d}}$ Continental crust after Krauskopf and Bird (1995)

\section{Geochemical modelling}

The results from the Physicochemical characterisation of eluates were used for geochemical modelling using the geochemical equilibrium model PHREEQC (Parkhurst and Appelo 2013) and MINTEQ.V4 database (Allison et al. 1991), to model the potential secondary mineral formation or dissolution.

A saturation index (SI) computed using PHREEQC indicated the thermodynamic tendency of a given mineral to precipitate or dissolve in the aqueous solutions. A negative SI indicated that the solution is not saturated with respect to a particular solid phase and that the solid phase would tend to dissolve if present, while a positive value indicated a tendency for the mineral to precipitate. A value close to zero suggested that the mineral was in equilibrium in the solution and may either precipitate or dissolve.

\section{Results and discussion}

\section{Mineralogical and chemical composition}

Since sulphide minerals are the most environmentally damaging minerals in mining waste (because of their unstable nature in surface atmospheric conditions and their potential for producing AMD), it was important to determine whether the WRs contained pyrite and other sulphide minerals. The XRD analyses carried out on the WRs (Table 2) revealed that they contained pyrite along with various other minerals (such as quartz, kaolinite, calcite and gypsum in WR1, kaolinite, haematite, gypsum and quartz in WR2 and quartz, kaolinite, malladerite, spangolite and franklinite in WR3). Therefore, the WRs were predicted to generate AMD, something which has been confirmed previously (Qureshi et al. 2019, 2016a). Minerals such as calcite and kaolinite can contribute towards 


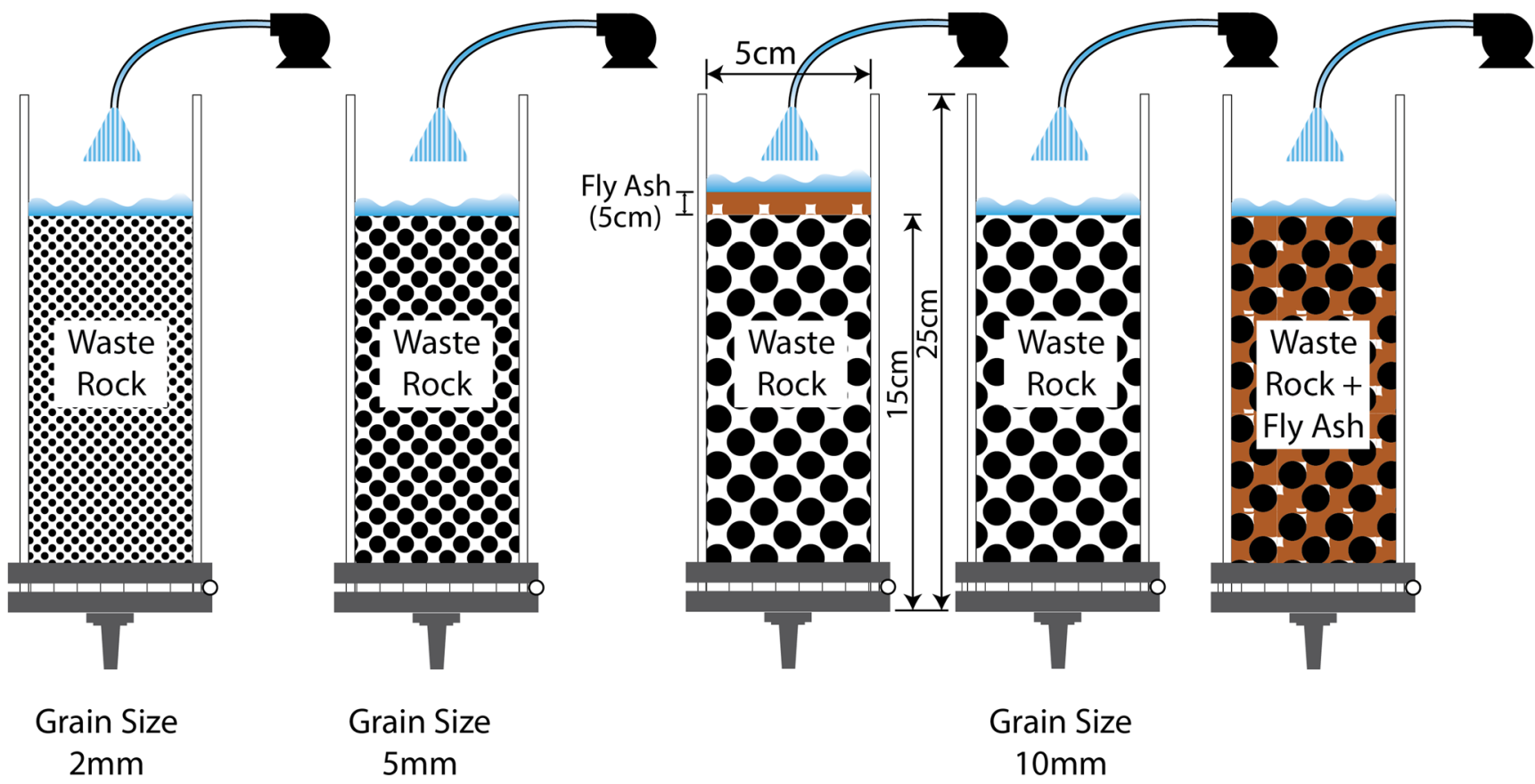

Fig. 1 Illustration of column leaching experiment

the self-neutralising potential of WRs, depending on $\mathrm{pH}$ levels. However, buffering by kaolinite is much less efficient than that of carbonates (Ritchie 1989).

The mineral composition of FA (Table 2) was dominated by ferric oxide followed by quartz, anhydrite, magnesioferrite and lime. Conventionally, the Ca-bearing minerals are considered responsible for the acid-neutralising potential of FA (Gitari et al. 2006), though silicates, $\mathrm{Fe}-$ and Al-oxides can also contribute to acid-buffering processes in low $\mathrm{pH}$ conditions (Lottermoser 2007).

The WR samples contained high concentrations of $\mathrm{Fe}$ and S (Table 3), varying from 1.5 to $10 \mathrm{wt} . \%$ and 1 to $11 \mathrm{wt} . \%$, respectively. The high sulphur content of the WRs is mainly due to the high sulphur coal in the field, as reported by Siddiqui (1999).

The concentrations of all the trace elements in the WRs were similar to their corresponding concentrations in the continental crust (CC; (Krauskopf and Bird 1995)), except for Ba (higher in $\mathrm{CC}$ ), $\mathrm{Cu}$ (lower in $\mathrm{CC}$ ) and $\mathrm{Sr}$ (higher in $\mathrm{CC}$ ). In contrast, almost all trace elements were found enriched in the FA compared to $\mathrm{CC}$, except for $\mathrm{Ba}$ (higher in $\mathrm{CC}$ ) and $\mathrm{Sr}$ (lower in CC).

Despite the relatively low concentrations of trace metals, the high $\mathrm{S}$ content suggests that some of these elements such as $\mathrm{Fe}, \mathrm{Mn}, \mathrm{As}, \mathrm{Cd}, \mathrm{Cu}, \mathrm{Hg}$ and $\mathrm{Zn}$ may occur in sulphide minerals in the WRs, and, under low $\mathrm{pH}$ conditions, become mobile. Nonetheless, Fe and other elements (such as $\mathrm{Si}, \mathrm{Al}, \mathrm{Ca}$ and $\mathrm{Mg}$ ) may contribute to secondary mineral formation and help sorption to take place by binding elements (by coprecipitation and/or adsorption) together while forming these secondary minerals, depending on the $\mathrm{pH}$ levels (Lottermoser 2007).

\section{Impact of particle size on AMD and leachate quality}

The effect of the WRs' particle size on $\mathrm{pH}$, Eh and EC (thus, AMD) is visible in Fig. 2. Although the differences in $\mathrm{pH}$ were not large, there were some differences in EC from all three columns, being highest in the column with the smallest particles $(\leq 2 \mathrm{~mm})$.

Chemical composition of the leachates from the WR1 columns (Table 4) shows differences in leaching of elements (such as $\mathrm{Fe}, \mathrm{SO}_{4}{ }^{2-}, \mathrm{Al}, \mathrm{Zn}, \mathrm{Co}, \mathrm{Cr}, \mathrm{Cu}, \mathrm{Mn}$ and $\mathrm{Ni}$ ) by varying the particle size of the samples. Such differences in concentrations indicate that the particle size is one of the driving forces behind the activity of AMD generating reactions and contamination of surrounding environment at mine sites.

This is mainly because the smaller particle sizes possess larger surface area and expose more sulphide mineral surfaces to oxygen and water, thus accelerating AMD generation. However, a sudden spike in $\mathrm{pH}$ and dip in EC, Eh and elemental leaching from the WR1 columns from the first to the second rinse indicate an initial flush-out effect, something that has also been observed previously (Qureshi et al. 2016a).

Because EC is very sensitive to the concentration of dissolved salts and $\mathrm{SO}_{4}{ }^{2-}$ concentrations in water, it has been used as a preliminary indicator of AMD in some studies (Gray 1996b; Lyew and Sheppard 2001; Galhardi and Bonotto 2016). Therefore, elevated EC (Fig. 2 g, h and i) and lower pH (Fig. 2 a and b; except WR3) 
$\rightarrow-10 \mathrm{~mm} \longrightarrow 5 \mathrm{~mm} \longrightarrow 2 \mathrm{~mm} \longrightarrow$ Mix $\multimap$ Cover

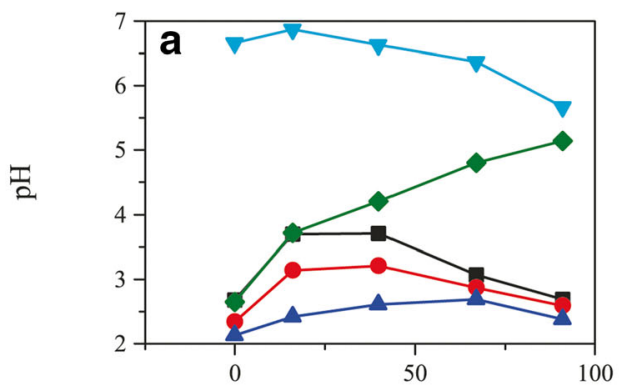

Time (Days)

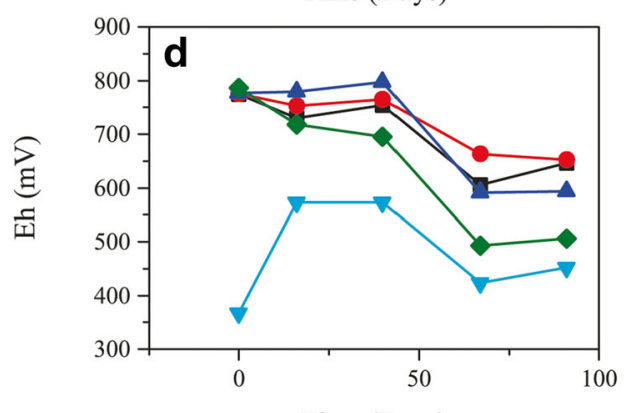

Time (Days)
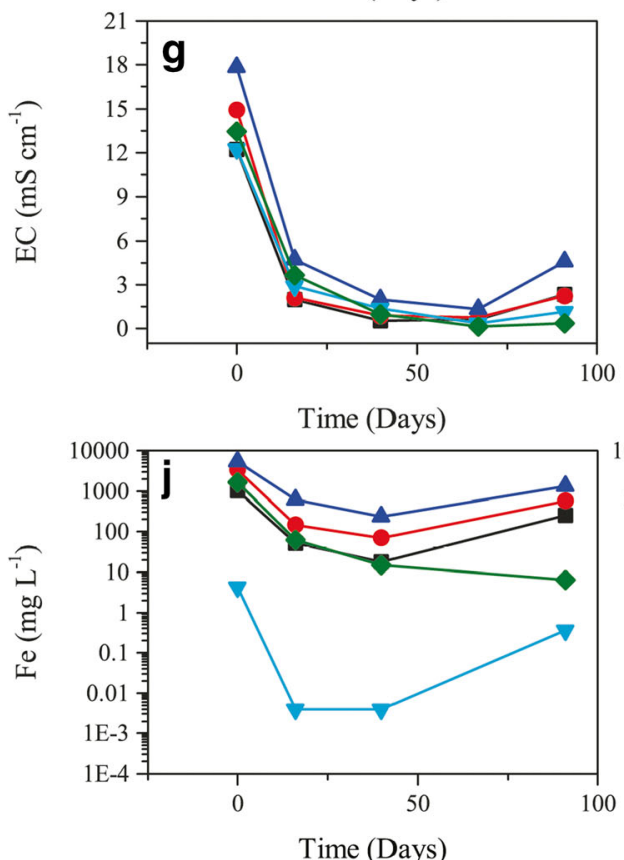

Fig. 2 Physicochemical characteristics of the leachates from CLE. a pH from WR1. b $\mathrm{pH}$ from WR2. $\mathrm{pH}$ from WR3. d Eh from WR1. e Eh from WR2. f Eh from WR3. g EC from WR1. h EC from WR2. i EC from

compared to columns with larger particles can indicate higher AMD generation in columns with smaller particle sizes. Moreover, elevating $\mathrm{pH}$ trends in the column with smallest particles of WR3 can also indicate that smaller particle sizes also expose more acid-buffering minerals (which might have precipitated due to natural weathering or secondary mineralisation during storage of the WR samples) which consume acidity, when the $\mathrm{pH}$ of the

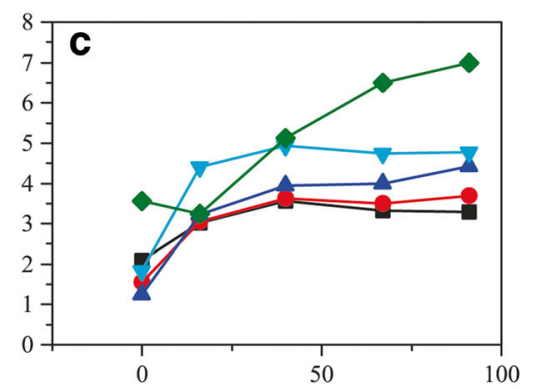

Time (Days)

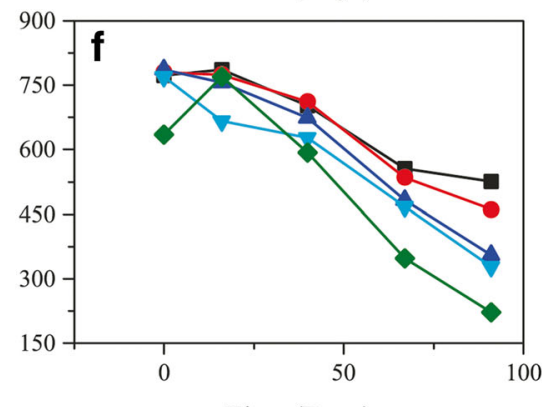

Time (Days)

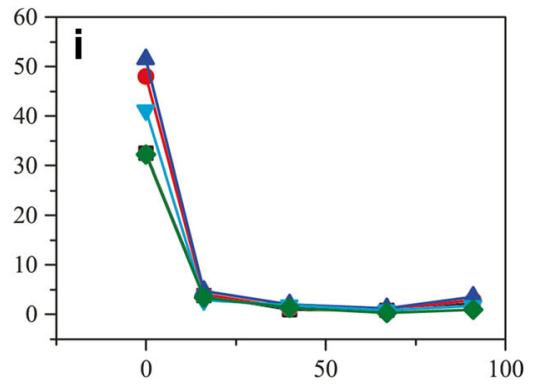

Time (Days)

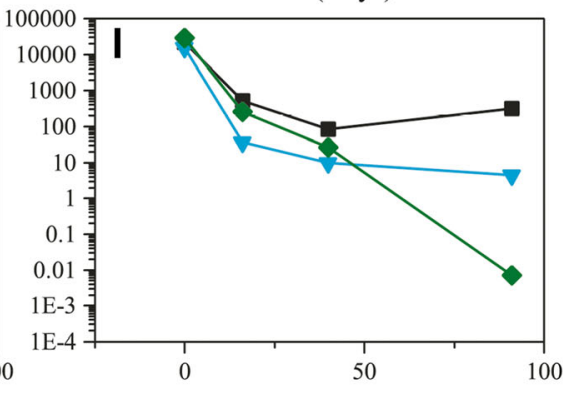

Time (Days)

Time (Days)

WR3. j Fe from WR1. $\mathbf{k}$ Fe from WR2. I Fe from WR3. $\mathbf{m}$ Ca from WR1. n Ca from WR2. o Ca from WR3. p SO ${ }_{4}{ }^{2-}$ from WR1. q $\mathrm{SO}_{4}{ }^{2-}$ from WR2. $\mathrm{r} \mathrm{SO}_{4}{ }^{2-}$ from WR3

system is acidic (Lottermoser 2007; Sánchez España 2007). Higher $\mathrm{pH}$ along with higher EC from the column with smallest particles of WR3 also indicate that secondary mineral formation is occurring slower in this column than other columns, which was not observed before during experiments performed on particles $\leq 1 \mathrm{~mm}$ for the same WR, and even with a smaller (FA:WR, 1:5) addition of FA (Qureshi et al. 2019). 

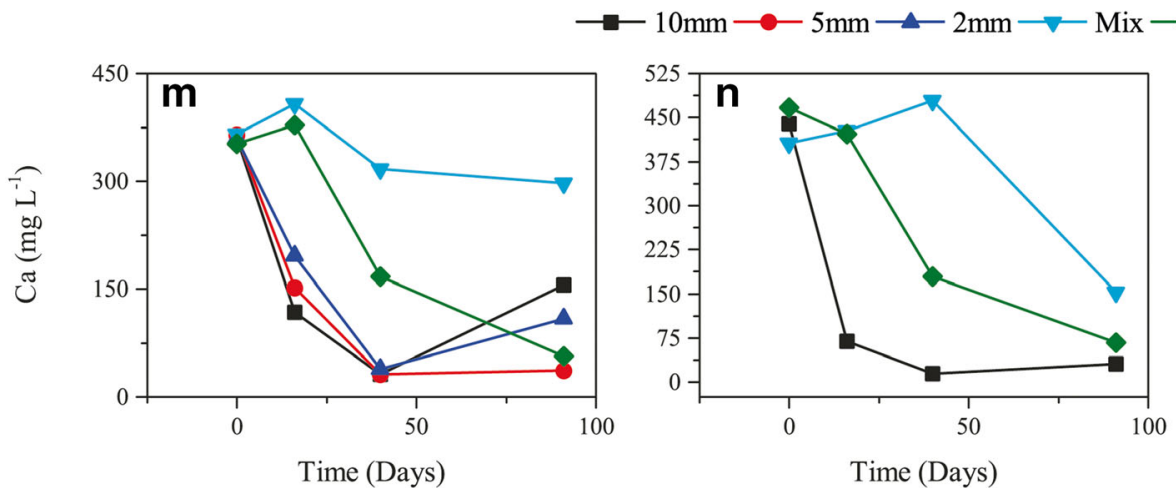

Cover
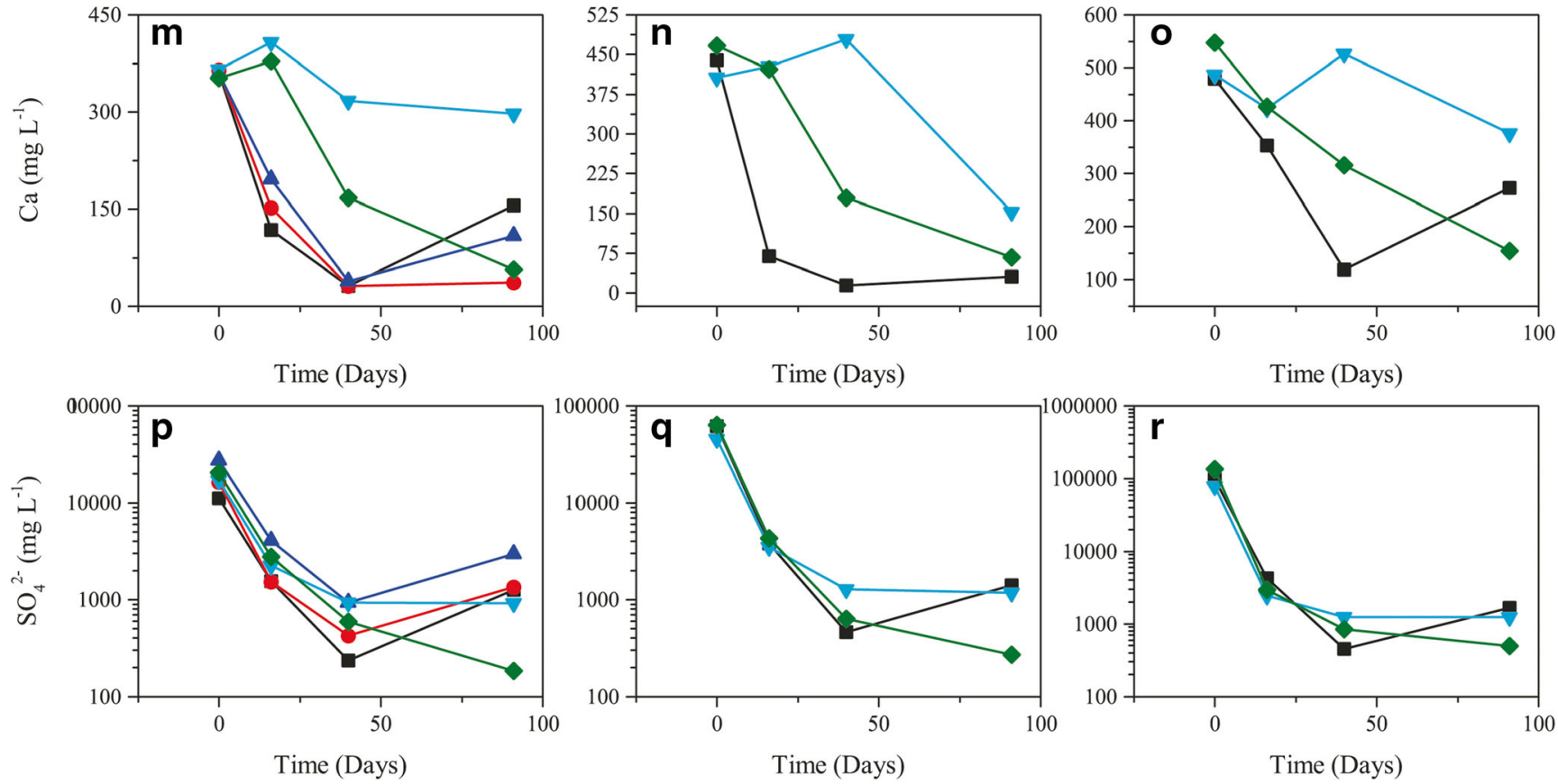

Fig. 2 continued.

Table 4 Minimum and maximum concentrations of the selected elements in eluates from WR1

\begin{tabular}{|c|c|c|c|c|c|c|}
\hline Element & Sample & $\begin{array}{l}10 \mathrm{~mm} \\
\text { Min-max }\end{array}$ & $\begin{array}{l}5 \mathrm{~mm} \\
\text { Min-max }\end{array}$ & $\begin{array}{l}2 \mathrm{~mm} \\
\text { Min-max }\end{array}$ & $\begin{array}{l}\text { Mixture } \\
\text { Min-max }\end{array}$ & $\begin{array}{l}\text { Cover } \\
\text { Min-max }\end{array}$ \\
\hline $\mathrm{pH}$ & & $2.68-3.71$ & $2.34-3.21$ & $2.13-2.61$ & $5.67-6.87$ & $2.65-5.14$ \\
\hline Eh & $\mathrm{mV}$ & $646.5-773.7$ & $652.5-775.5$ & 593.6-796.7 & $367.1-573.6$ & $505.7-786.6$ \\
\hline $\mathrm{EC}$ & $\mathrm{mS} / \mathrm{cm}$ & $0.535-12.21$ & $0.891-14.94$ & $1.975-17.84$ & $1.159-12.28$ & $0.378-13.44$ \\
\hline $\mathrm{Ca}$ & $\mathrm{mg} / 1$ & $31.6-360$ & $31.5-364$ & $38.4-359$ & $297-408$ & $56.4-378$ \\
\hline $\mathrm{Fe}$ & $\mathrm{mg} / \mathrm{l}$ & $17.6-1020$ & $69.4-3320$ & $239-5290$ & $0.004-4.3$ & $6.36-1640$ \\
\hline $\mathrm{K}$ & $\mathrm{mg} / 1$ & $0.54-12$ & $0.5-11.4$ & $3-11.3$ & $1.13-14.9$ & $1.4-15.7$ \\
\hline $\mathrm{Mg}$ & $\mathrm{mg} / \mathrm{l}$ & $25.2-1070$ & $27.8-1440$ & $24.9-1450$ & $29.4-1840$ & $7.06-1380$ \\
\hline $\mathrm{Na}$ & $\mathrm{mg} / \mathrm{l}$ & $5.01-521$ & $4.28-539$ & $4.71-483$ & $8.48-1390$ & $7.48-1040$ \\
\hline $\mathrm{Cl}$ & $\mathrm{mg} / \mathrm{l}$ & $5.87-464$ & $7.78-552$ & $8.99-506$ & $1.89-993$ & $2.55-876$ \\
\hline $\mathrm{F}$ & $\mathrm{mg} / 1$ & $0.2-0.825$ & $0.2-1.23$ & $0.2-1.71$ & $0.266-6.02$ & $0.2-6.64$ \\
\hline $\mathrm{SO}_{4}{ }^{2-}$ & $\mathrm{mg} / \mathrm{l}$ & $235-11,200$ & $425-16,500$ & $929-27,200$ & $916-17,100$ & $183-20,600$ \\
\hline DOC & $\mathrm{mg} / 1$ & $3.61-80.1$ & $3.11-167$ & $8.61-216$ & $0.87-112$ & $3.2-131$ \\
\hline $\mathrm{Al}$ & $\mathrm{mg} / 1$ & $2.28-134$ & $6.81-429$ & $15.2-628$ & $0.002-0.196$ & $0.114-258$ \\
\hline $\mathrm{Zn}$ & $\mathrm{mg} / 1$ & $2.13-108$ & $2.06-198$ & $1.59-203$ & $0.661-10.6$ & $2.11-67.1$ \\
\hline As & $\mu \mathrm{g} / \mathrm{l}$ & $0.5-12$ & $0.5-51.4$ & $1.24-98.9$ & $0.5-0.575$ & $0.5-37.8$ \\
\hline $\mathrm{Ba}$ & $\mu \mathrm{g} / 1$ & $4.61-43.9$ & $3.16-38.5$ & $4.97-36.6$ & $25.4-46.7$ & $10.6-36$ \\
\hline $\mathrm{Cd}$ & $\mu \mathrm{g} / \mathrm{l}$ & $0.674-19.5$ & $1.19-51.3$ & $2.43-62.2$ & $0.426-1.55$ & $0.251-32.1$ \\
\hline Co & $\mu \mathrm{g} / 1$ & $65.4-4490$ & $132-8140$ & $254-9540$ & $31.7-1510$ & $27.7-4580$ \\
\hline $\mathrm{Cr}$ & $\mu \mathrm{g} / 1$ & $13.1-476$ & $40.1-1820$ & $107-2090$ & $0.5-0.82$ & $2.83-612$ \\
\hline $\mathrm{Cu}$ & $\mu \mathrm{g} / 1$ & $19.7-514$ & $44.1-1280$ & $210-2160$ & $1-3.86$ & $6.4-1030$ \\
\hline $\mathrm{Mn}$ & $\mu \mathrm{g} / \mathrm{l}$ & $261-6770$ & $648-18,600$ & $1140-24,900$ & $341-14,600$ & $184-10,600$ \\
\hline $\mathrm{Ni}$ & $\mu \mathrm{g} / 1$ & $98.2-6170$ & $212-11,600$ & $469-14,400$ & $42-2040$ & $39.3-6750$ \\
\hline $\mathrm{Pb}$ & $\mu \mathrm{g} / 1$ & $0.316-16$ & $2.88-50.1$ & 48.9-202 & $0.2-0.2$ & $0.2-9.76$ \\
\hline
\end{tabular}


Despite the chemical composition of the leachates from the WR2 and WR3 columns were not determined, their comparative $\mathrm{pH}$ and $\mathrm{EC}$ with WR1 can be indicative of the sulphide reactivity and elemental leaching. Furthermore, due to dependence of element mobility on $\mathrm{pH}$, lower $\mathrm{pH}$ conditions and higher EC also suggest that the elemental concentrations would also be high in the leachates from WR2 and WR3.

\section{Impact of co-disposal of FA and WRs on AMD and leachate quality}

\section{Co-disposal by FA and WR mixture}

FA addition has shown to have considerable influence on $\mathrm{pH}$ and other physicochemical characteristics of the leachates regardless of the FA addition method (Fig. 2 and Tables 4 and $5)$, but the efficiency differed between the methods and the WR samples. For instance, in the mixture scenario in WR1, $\mathrm{pH}$ of the leachate is always circumneutral, and, due to the fact that $\mathrm{pH}$ plays a crucial role in elemental leaching (Lottermoser 2007; Izquierdo and Querol 2012), elements associated with sulphide minerals (such as $\mathrm{Fe}, \mathrm{Al}, \mathrm{Zn}, \mathrm{As}, \mathrm{Cd}, \mathrm{Co}, \mathrm{Cr}$ and $\mathrm{Cu}$ ) were always relatively low except on the first rinse where the flush-out effect took place.

However, a decreasing pattern of $\mathrm{pH}$ over the duration of the experiment has been observed in the same (mixture) column in WR1. This indicates that the secondary mineralisation (such as precipitation of goethite and ferrihydrite; Fig. 3) contributes towards the acidity of the solution (Lottermoser 2007). This could also indicate that the neutralisation provided by FA is not enough for complete neutralisation of the acidity produced by the reactivity of sulphide minerals and by secondary mineralisation. This may sometimes happen due to depletion of acid-neutralising minerals supplied by FA or when they become non-reactive due to secondary mineral coating (encapsulation) on their surfaces (Lottermoser 2007). The latter is probably not the case here, as indicated by presence of $\mathrm{Ca}$ in solution (Fig. $2 \mathrm{~m}$ ).

In general, the leachates from WR2 were constantly acidic regardless of the method of FA addition throughout the test duration, but small differences in $\mathrm{pH}$ (higher), EC (lower) and pronounced leaching of elements (such as $\mathrm{Fe}, \mathrm{Ca}, \mathrm{Mg}, \mathrm{Na}, \mathrm{Cl}$ and F) with FA addition compared to the columns without FA are visible in Fig. 2 and Table 5.

Table 5 Minimum and maximum concentrations of the selected elements in eluates from WR2 and WR3

\begin{tabular}{|c|c|c|c|c|c|c|c|}
\hline Element & Sample & $\begin{array}{l}\text { WR2 }(10 \mathrm{~mm}) \\
\text { Min-max }\end{array}$ & $\begin{array}{l}\text { WR2 (mix) } \\
\text { Min-max }\end{array}$ & $\begin{array}{l}\text { WR2 (cover) } \\
\text { Min-max }\end{array}$ & $\begin{array}{l}\text { WR3 }(10 \mathrm{~mm}) \\
\text { Min-max }\end{array}$ & $\begin{array}{l}\text { WR3 (mix) } \\
\text { Min-max }\end{array}$ & $\begin{array}{l}\text { WR3 (cover) } \\
\text { Min-max }\end{array}$ \\
\hline $\mathrm{pH}$ & & $1.99-2.87$ & $3.54-4.04$ & $2.2-4.08$ & $2.09-3.56$ & $3.56-4.93$ & $1.84-7$ \\
\hline Eh & $\mathrm{mV}$ & $572-801$ & 543-798 & $552-788$ & $526-786$ & $328-770$ & $222-769$ \\
\hline $\mathrm{EC}$ & $\mathrm{mS} / \mathrm{cm}$ & $1.08-26.3$ & $1.483-22.62$ & $0.533-27.23$ & $0.995-32.51$ & $1.73-41.2$ & $0.92-32.29$ \\
\hline $\mathrm{Ca}$ & $\mathrm{mg} / \mathrm{l}$ & $15-439$ & $153-479$ & $67.6-467$ & $119-479$ & $376-526$ & $154-547$ \\
\hline $\mathrm{Fe}$ & $\mathrm{mg} / \mathrm{l}$ & $128-12,500$ & $2.04-3160$ & $38.6-10,300$ & $83.1-21,800$ & $4.54-15,800$ & $0.01-29,000$ \\
\hline $\mathrm{K}$ & $\mathrm{mg} / \mathrm{l}$ & $3-10$ & $0.635-10$ & $0.5-14$ & $0.5-43.4$ & $0.5-10$ & $0.5-55.9$ \\
\hline $\mathrm{Mg}$ & $\mathrm{mg} / \mathrm{l}$ & $8.67-2040$ & $6.74-3110$ & $3.55-2400$ & $40.6-1460$ & $25.2-2920$ & $25.2-2920$ \\
\hline $\mathrm{Na}$ & $\mathrm{mg} / \mathrm{l}$ & $2.07-667$ & $10.2-1870$ & $5.83-1410$ & $2.93-616$ & $7.27-2110$ & $7.27-2110$ \\
\hline $\mathrm{Cl}$ & $\mathrm{mg} / \mathrm{l}$ & $4.34-706$ & $1.69-946$ & $2.69-886$ & $2.41-324$ & $1-624$ & $1-624$ \\
\hline $\mathrm{F}$ & $\mathrm{mg} / \mathrm{l}$ & $0.2-3.55$ & $0.2-90.4$ & $0.2-17.6$ & $0.2-8.19$ & $0.2-78.3$ & $0.2-78.3$ \\
\hline SO42- & $\mathrm{mg} / \mathrm{l}$ & 464-61,600 & $1180-45,700$ & $269-63,600$ & $455-98,100$ & $1240-79,200$ & $1240-79,200$ \\
\hline DOC & $\mathrm{mg} / \mathrm{l}$ & $4.75-272$ & $3.1-184$ & $2.22-258$ & $2.44-233$ & $0.52-183$ & $0.52-183$ \\
\hline $\mathrm{Al}$ & $\mathrm{mg} / \mathrm{l}$ & $8.52-2200$ & $25-2340$ & $1.96-2180$ & $5.11-3220$ & $1.23-4250$ & $1.23-4250$ \\
\hline $\mathrm{Zn}$ & $\mathrm{mg} / \mathrm{l}$ & $1.07-287$ & $1.78-218$ & $0.395-191$ & $0.574-266$ & $0.74-214$ & $0.74-214$ \\
\hline As & $\mu \mathrm{g} / 1$ & $0.589-447$ & $0.5-15$ & $0.5-477$ & $0.5-297$ & $0.5-274$ & $0.5-460$ \\
\hline $\mathrm{Ba}$ & $\mu \mathrm{g} / \mathrm{l}$ & $2.74-26.9$ & $21.2-59.7$ & $10.5-19.4$ & $9.09-58.4$ & $28.9-43.2$ & $4.49-45.5$ \\
\hline $\mathrm{Cd}$ & $\mu \mathrm{g} / 1$ & $1.56-151$ & $2.31-114$ & $0.847-135$ & $0.468-109$ & $0.61-99.6$ & $0.05-140$ \\
\hline Co & $\mu \mathrm{g} / \mathrm{l}$ & $130-24,500$ & $96.8-21,100$ & $28.2-22,300$ & $39.5-10,600$ & $20-12,300$ & $0.86-11,400$ \\
\hline $\mathrm{Cr}$ & $\mu \mathrm{g} / 1$ & $57.6-5510$ & $6.34-1460$ & $10.5-4570$ & $15.3-6460$ & $0.5-3060$ & $0.5-8390$ \\
\hline $\mathrm{Cu}$ & $\mu \mathrm{g} / 1$ & $173-11,100$ & $49.7-2500$ & $28-9610$ & $19.3-2720$ & $3.95-867$ & $1-2330$ \\
\hline $\mathrm{Mn}$ & $\mu \mathrm{g} / 1$ & $450-49,500$ & $243-47,600$ & $147-46,200$ & $501-55,500$ & $374-72,500$ & $294-68,400$ \\
\hline Mo & $\mu \mathrm{g} / \mathrm{l}$ & $0.5-30.7$ & $0.5-10$ & $0.5-45.3$ & $0.5-50.9$ & $0.5-108$ & $0.5-77.8$ \\
\hline $\mathrm{Ni}$ & $\mu \mathrm{g} / 1$ & $242-36,000$ & $194-30,200$ & $72.1-31,100$ & $50.1-12,000$ & $32.3-15,700$ & $1.61-14,200$ \\
\hline $\mathrm{Pb}$ & $\mu \mathrm{g} / 1$ & $16.7-1770$ & $0.2-4$ & $2.56-1370$ & $0.371-899$ & $0.2-20$ & $0.2-1080$ \\
\hline
\end{tabular}


Leachates from the column with FA mixture in WR2 started with low $\mathrm{pH}(\sim 3.5)$ and stayed acidic throughout the test duration with $\mathrm{pH} \sim 4$ on the conclusion of the test. Moreover, this was twice as high as compared to columns without $\mathrm{FA}$ addition, indicating that the buffering reactions are taking place but their reactivity is slower compared to acid-producing reactions (Alakangas et al. 2013). Despite such low $\mathrm{pH}$ conditions from this column, FA addition stabilised $\mathrm{pH}$ between 3.5 and 4 which is enough for the precipitation of $\mathrm{Fe}^{3+}$ secondary minerals (or lowering their dissolution; Fig. 3) and removal of $\mathrm{Fe}$ from the solution (Wei et al. 2005; Balintova and Petrilakova 2011) (see Fig. $2 \mathrm{k}$. However, acidity produced by secondary mineralisation (Lottermoser 2007) can also lower the $\mathrm{pH}$ of the solution and that might also be a reason behind constantly acidic leachates from this column.

WR3 is the most acidic in the collection of WR samples in this study (Table 1 and Qureshi et al. (2016a)). Leachates from the mixture column in WR3 start with acidic $\mathrm{pH}(\sim 2)$ but get elevated to around $\mathrm{pH} \sim 4.4$ on the second rinse and constantly remain in the range $\mathrm{pH} \sim 4.7-4.9$ (Fig. 2 and Table 5). Sudden elevation in $\mathrm{pH}$ can be attributed to FA which is available within the pores between WR particles and buffers acidity as soon as it is produced. Despite that, the low $\mathrm{pH}$ conditions are probably because the $\mathrm{pH}$ is constantly within the range suitable for $\mathrm{Fe}^{3+}$ precipitation (Wei et al. 2005; Balintova and Petrilakova 2011) which produces more acidity (Lottermoser 2007) than the buffering minerals can consume, resulting in $\mathrm{pH}$ stabilisation after the 2 nd rinse. Moreover, dissolution of $\mathrm{Fe}^{3+}$ and $\mathrm{Al}$ minerals as indicated by PHREEQC (Fig. 3) can be associated to their capability of acting as buffers when $\mathrm{pH}$ conditions tend to be acidic (Lottermoser 2007; Sánchez España 2007).

\section{Co-disposal by FA cover}

The cover scenario in WR1 has been quite different than mixture in every aspect (Fig. 2 and Table 4). It starts with low pH conditions $(\sim 2.6)$ and keeps improving until 5 th rinse $(\sim 5.1)$. Such changes in $\mathrm{pH}$ indicate that the available oxygen within the column depletes with time and oxygen diffusion has been restricted by the FA cover on top, which usually happens when applying dry covers (Höglund et al. 2004; Mäkitalo et al. 2016).

Alternatively, the preferential flow, which causes high $\mathrm{pH}$ water (produced by FA cover on top) to pass through certain pathways throughout the column without interacting with the whole material, could also be a reason behind higher $\mathrm{pH}$ and lower elemental concentration in the leachates. However, this does not seem to be a case here, as indicated by constantly decreasing $\mathrm{SO}_{4}{ }^{2-}, \mathrm{Ca}, \mathrm{Fe}, \mathrm{EC}$ and $\mathrm{Eh}$, while increasing $\mathrm{pH}$ (Fig. 2).
The cover column from WR2 starts with low $\mathrm{pH}(\sim 2)$ and improves rapidly with maximum $\mathrm{pH} \sim 4$ and 3.8 on the concluding day of the test. The lowering of $\mathrm{pH}$ from $\sim 4$ on the 67th day of the test to $\sim 3.8$ on the 91 st day is probably due to secondary mineralisation within the column which produces acidity (Lottermoser 2007) since the $\mathrm{Fe}^{3+}$ minerals start to precipitate at $\mathrm{pH} \geq 3.5$ (Wei et al. 2005; Balintova and Petrilakova 2011). This has also been observed in Fig. $2 \mathrm{k}$ by constantly decreasing Fe concentrations in solution. EC of the leachates was little higher compared to the mixture column in first two rinses but stays relatively low afterwards. Flush-out effects may be reason behind such high EC, but it can also be due secondary mineralisation and elevating $\mathrm{pH}$ conditions that restrict elemental mobility.

Utilisation of FA as cover has been effective to neutralise strong acidity and/or prevent further acidity within the test duration and restrict element mobility to considerable extent from WR3. In the beginning, it produces strongly acidic leachates but $\mathrm{pH}$ rapidly and constantly elevated being highest at the conclusion of the test ( $\mathrm{pH} \sim 7$; Fig. 2c). Due to constant improvement (elevation) of $\mathrm{pH}$, leaching of the elements has also been decreasing.

FA cover performs better than mixture, probably because (with time), similar to its counterpart in WR1, it restricts diffusion of fresh oxygen into the column, which slows down the weathering reactions on overall and results in constant increments in the $\mathrm{pH}$ and reduces elemental mobility (Fig. 2). It can also be because the FA provides acidbuffering minerals (and high $\mathrm{pH}$ waters) slowly and constantly which allows buffering reactions to take place consistently rather than rapidly. The slow release of buffering minerals and their transport down into the column can allow more time for the buffering reactions to take place effectively (Fig. 3). Furthermore, despite the secondary mineralisation (especially precipitation of $\mathrm{Fe}^{3+}$-hydroxides and -oxyhydroxides; Fig. 3) and decreasing $\mathrm{Ca}^{2+}$ (Fig. 2), the incremental $\mathrm{pH}$ can be indicative of the additional buffering supplied by the secondary $\mathrm{Fe}$ (such as jarosites tend to dissolve at the end; Fig. 3) and $\mathrm{Al}$ minerals (constant dissolution of $\mathrm{AlOHSO}_{4}$, alunite, gibbsite and diaspore; Fig. 3).

\section{Prospects of FA and WR co-disposal}

Despite the FA used here possessed significantly less acidneutralising potential compared to a biomass FA (20 kg $\mathrm{CaCO}_{3}$ tonne ${ }^{-1}$ compared to $275 \mathrm{~kg} \mathrm{CaCO}_{3}$ tonne $^{-1}$, respectively) in our previous study (Qureshi et al. 2016b), its addition has been considerably effective for neutralisation and/or reduction in AMD from the WRs during the CLE.

The WRs also behaved differently in our previous study (Qureshi et al. 2016a); for instance, WR1 produced circumneutral $\mathrm{pH}$ leachates during a weathering cell 
a

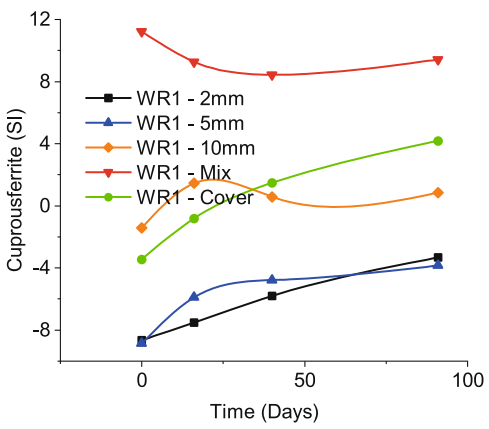

b

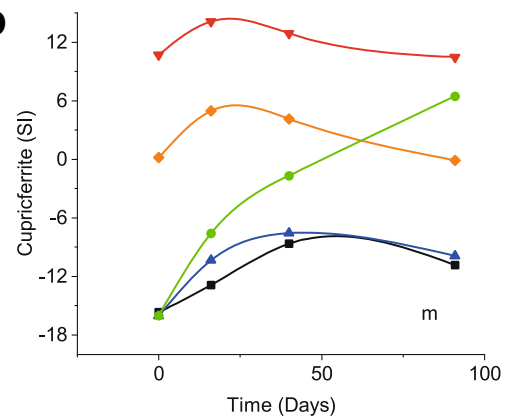

C

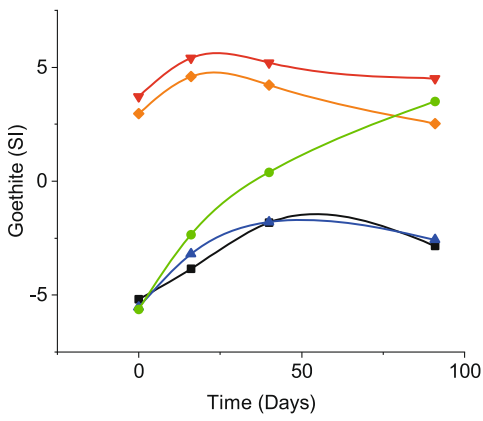

d

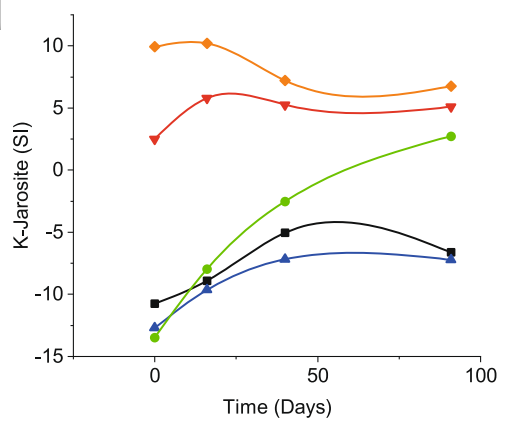

e

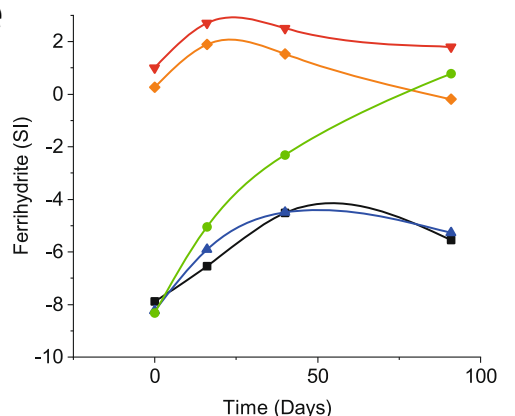

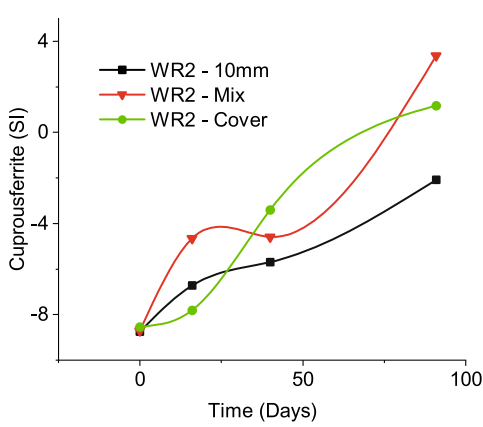
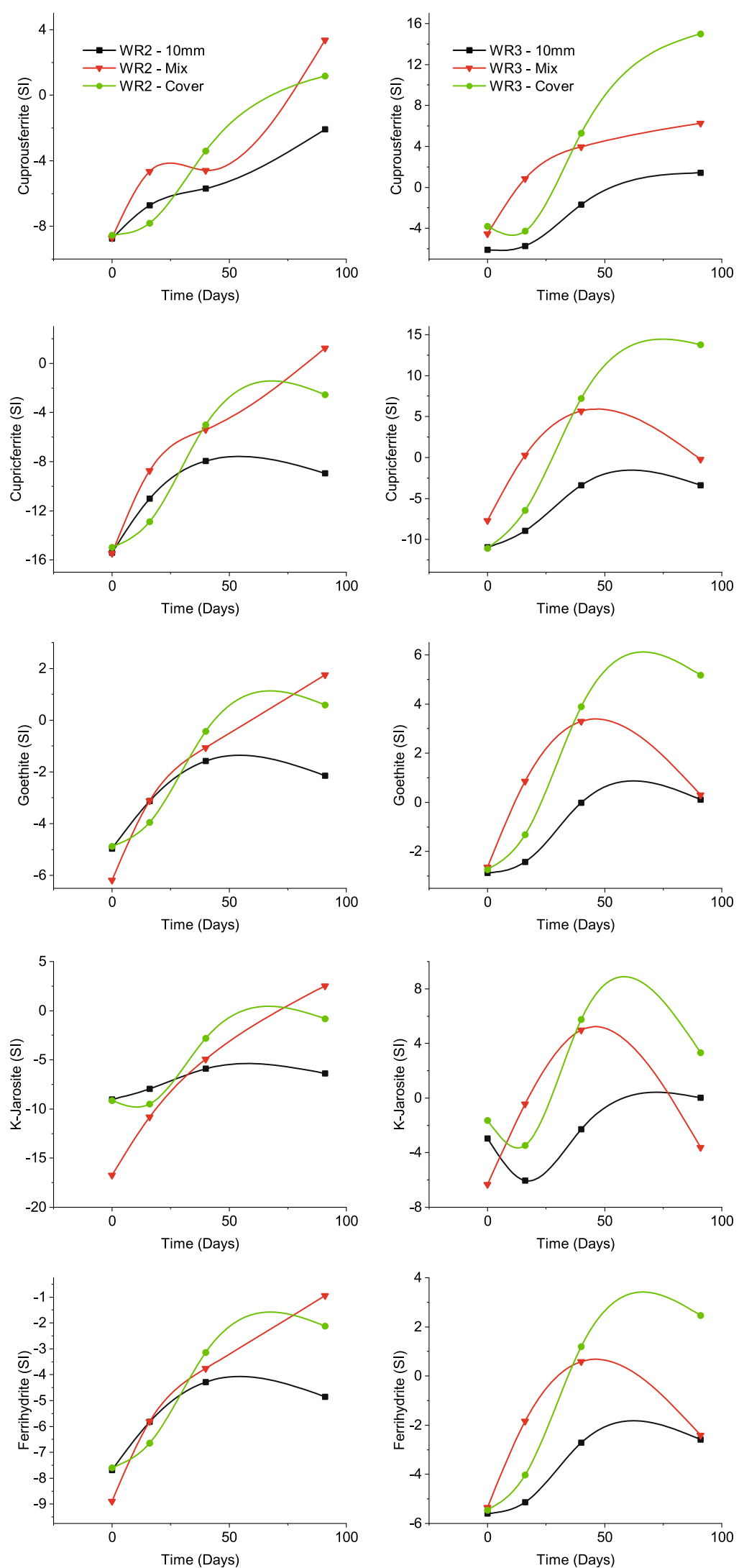

Fig. 3 Saturation Index (SI) for selected minerals as computed by PHREEQC (left, WR1; centre, WR2; and right, WR3). a Cuprousferrite. b Cupricferrite. c Goethite. d K-Jarosite. e Ferrihydrite. f Na-Jarosite. g AlOHSO ${ }^{4}$. h Alunite. i Gibbsite. j Diaspore 

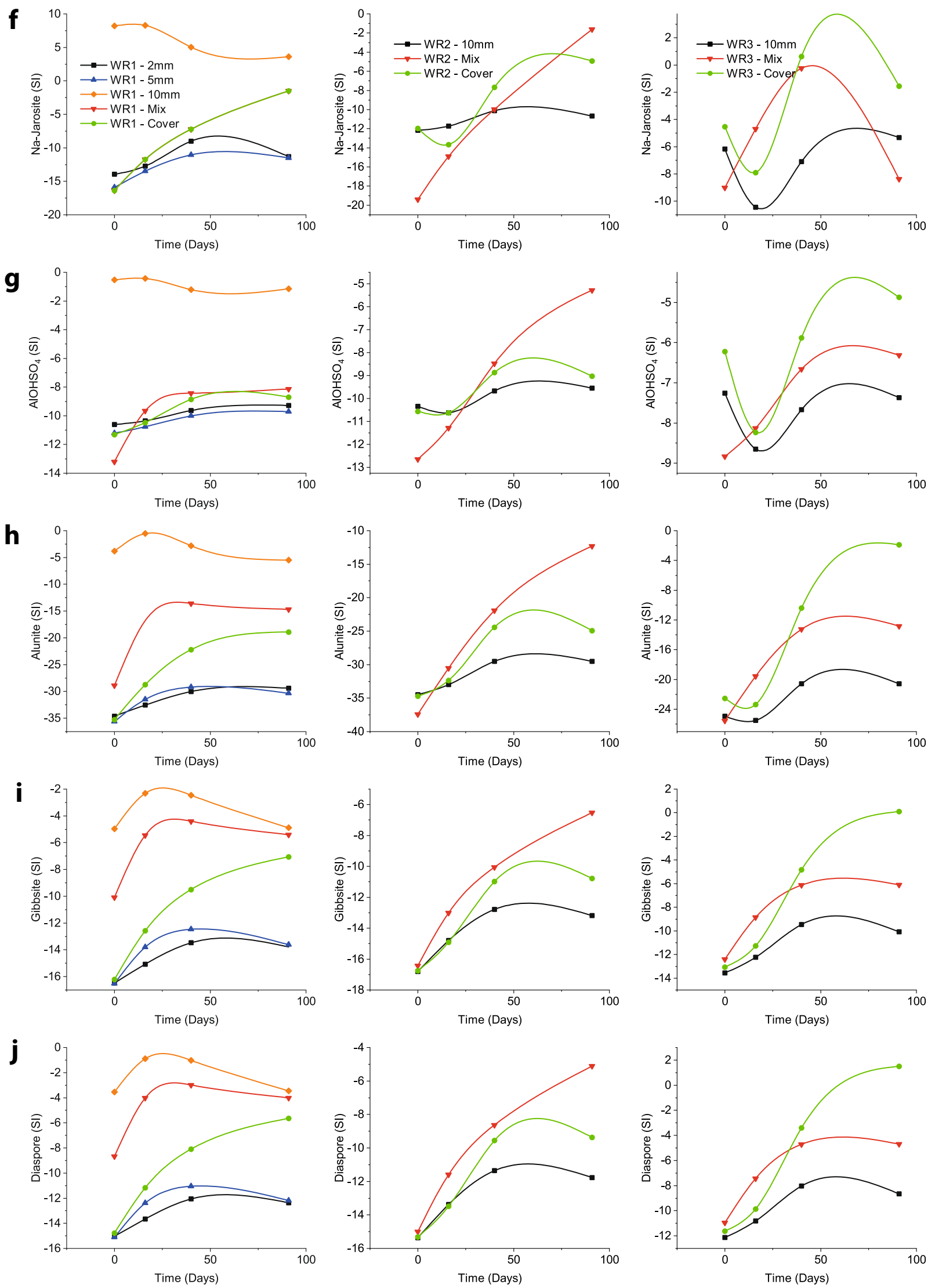

Fig. 3 (continued). 
experiment for 192 days, probably because the chemical composition of the WR1 $(n=3)$ varies significantly as indicated by its $\mathrm{Ca}(3.69 \pm 5.64), \mathrm{Fe}(3.9 \pm 4.26)$ and $\mathrm{S}(10.7 \pm 12)$ content (Table 2; (Qureshi et al. 2016a)). However, the leachates from WR2 and WR3 were mildly ( $\mathrm{pH} \sim 2.7-4.9$ ) and strongly ( $\mathrm{pH} \sim 0.9-2.3$ ) acidic, respectively, in our previous study (Qureshi et al. 2016a).

It has been observed from the results that co-disposal by mixture works almost instantaneously (indicated by slightly higher $\mathrm{pH}$ and lower EC; Fig. 2), but it seems that the secondary mineralisation (especially secondary $\mathrm{Fe}$ and $\mathrm{Al}$ minerals) dominate the system over time and contributes towards acidity, which causes $\mathrm{pH}$ stabilisation to $\sim 4.5-5$. Such secondary mineralisation can remove $\mathrm{Fe}^{2+} / \mathrm{Fe}^{3+}$ from the solution, bind toxic elements (such as $\mathrm{As}, \mathrm{Pb}, \mathrm{Cu}, \mathrm{Zn}, \mathrm{Cd}, \mathrm{Co}, \mathrm{Ni}$ and $\mathrm{Mn}$ ) and act as buffers when $\mathrm{pH}$ conditions tend to be more acidic (Lottermoser 2007; Sánchez España 2007). Therefore, co-disposal by mixture can be considered a rapid and effective method for disposing FA and WRs where materials are not strongly acid-generating and need additional buffering capacity to improve their environmental performance.

Utilising FA as cover material for WR dumps, on the other hand, behaves differently from the mixture. Because FA is available on the top (covering surface), the acidity generated from the WRs deep down in the columns is not neutralised by FA in the beginning (indicated by low $\mathrm{pH}$ and high EC, Fig. 2), but by $\mathrm{Fe}$ and $\mathrm{Al}$ minerals instead due to acidic pH conditions (Fig. 3; (Lottermoser 2007; Sánchez España 2007)). Furthermore, the cover effect (reducing oxygen migration) seems to take place which reduces sulphide minerals' reaction rate and supplies acidneutralising capacity gradually, causing gradual rise in $\mathrm{pH}$. Such gradual changes in $\mathrm{pH}$ conditions also help the secondary minerals to precipitate and/or reduce their dissolution. The acidity produced by secondary mineralisation is not affecting the overall $\mathrm{pH}$ of the system because the reactivity of the acid-producing reactions (oxidation of sulphide minerals) has been reduced due to the depletion of available oxygen within the system and slower supply of fresh oxygen because of the cover effect.

Although FA has been effective for neutralisation and/ or slowing down AMD generation, its addition pronounces concentrations of elements in leachates that are mostly enriched in FA (such as $\mathrm{Ca}, \mathrm{Na}, \mathrm{Cl}, \mathrm{F}, \mathrm{Mo}, \mathrm{Ba}$ and $\mathrm{SO}_{4}{ }^{2-}$ ). Therefore, FA's utilisation for the remediation, mitigation, neutralisation or prevention of AMD warrants special attention because mobility of many elements is $\mathrm{pH}$-dependant and if the $\mathrm{pH}$ conditions tend to be acidic, FA might contribute in additional contamination. Notwithstanding, the results of this study support the codisposal of FA with acid-generating WRs to improve AMD situation at the Lakhra coal field.

\section{Conclusions}

The effect of particle size has been clearly observed in WR1 where smaller particle sizes produced leachates with elevated concentrations of the sulphide related elements (such as $\mathrm{Al}$, $\mathrm{Co}, \mathrm{Cr}, \mathrm{Cu}, \mathrm{Fe}, \mathrm{Mn}, \mathrm{Ni}, \mathrm{SO}_{4}{ }^{2-}$ and $\mathrm{Zn}$ ), indicating that sulphide oxidation has been pronounced in smaller particles. Similarly, low $\mathrm{pH}$ leachates with high EC from the other two WRs also indicate that the columns with smaller particle sizes of WRs 2 and 3 possess higher AMD-generating potential. However, slightly higher $\mathrm{pH}$ leachates from the smaller particle size WR3 columns were probably due to presence of some $\mathrm{Fe}$ and $\mathrm{Al}$ minerals that neutralise the $\mathrm{pH}$, resulting in higher EC.

Co-disposal of FA as mixture readily provided acidbuffering minerals, resulting in better start-up $\mathrm{pH}$ conditions and leachate quality, compared to WRs alone. However, acidity produced by secondary mineralisation contributed towards the acidification of the system, causing stabilisation of $\mathrm{pH}$ at around 4.5-5. In contrast, the $\mathrm{pH}$ of the leachates from the FA cover scenario gradually increased from strongly acidic to mildly acidic (WR1 and WR2) and circumneutral (WR3) along with decrease in EC and elemental leaching. Gradually increasing $\mathrm{pH}$ was caused by the cover effect, which reduced oxygen diffusion, thus reducing sulphide oxidation, and causing $\mathrm{pH}$ to elevate. Because $\mathrm{pH} \sim 4-5$ is sufficient for secondary $\mathrm{Fe}$ and $\mathrm{Al}$ mineral precipitation (which also removes toxic elements), the FA cover performs well to achieve this pH until the conclusion of the CLE. However, due to slower supply of acid neutralisation into the system, acidity produced in the beginning could not be neutralised.

The co-disposal of FA as cover and/or mixture possesses potential for partial neutralisation and/or slowing down AMD production and improving leachate quality. However, both systems need to be scaled up and investigated for AMD neutralisation, leachate quality and geotechnical stability by long-term experiments and kinetic modelling.

Acknowledgements The authors wish to thank the administration at Lakhra Power Station and Lakhra Coal Mines, Pakistan.

Author contribution AQ, CM and BÖ performed the study conception and design. AQ performed the sampling, sample preparations, laboratory experiments and analyses. AQ performed the data collection and curation. $\mathrm{AQ}, \mathrm{CM}$ and $\mathrm{BÖ}$ contributed in interpretation of the results. $\mathrm{CM}$ and BÖ supervised the research work. The first draft was written by AQ. All authors commented on previous versions of the manuscript and all authors read and approved the final manuscript.

Funding Open access funding provided by Lulea University of Technology. The division of Geosciences and Environmental Engineering at Luleå University of Technology, Sweden, provided the research expenses through Center for Advanced Mining and Metallurgy 
$\left(\mathrm{CAMM}^{2}\right)$, and Higher Education Commission of Pakistan financed the stay of the corresponding author in Sweden.

Availability of data and materials All data generated or analysed during this study are included in this manuscript.

\section{Declarations}

Ethics approval and consent to participate Not applicable.

Consent for publication Not applicable.

Competing interests The authors declare no competing interests.

Open Access This article is licensed under a Creative Commons Attribution 4.0 International License, which permits use, sharing, adaptation, distribution and reproduction in any medium or format, as long as you give appropriate credit to the original author(s) and the source, provide a link to the Creative Commons licence, and indicate if changes were made. The images or other third party material in this article are included in the article's Creative Commons licence, unless indicated otherwise in a credit line to the material. If material is not included in the article's Creative Commons licence and your intended use is not permitted by statutory regulation or exceeds the permitted use, you will need to obtain permission directly from the copyright holder. To view a copy of this licence, visit http://creativecommons.org/licenses/by/4.0/.

\section{References}

Alakangas L, Andersson E, Mueller S (2013) Neutralization/prevention of acid rock drainage using mixtures of alkaline by-products and sulfidic mine wastes. Environ Sci Pollut Res 20:7907-7916. https://doi.org/10.1007/s11356-013-1838-z

Allison JD, Brown DS, Novo-Gradac KJ (1991) MINTEQA2/ PRODEFA2, A geochemical assessment model for environmental systems: Version 3.0 User's Manual

Bäckström M, Sartz L (2011) Mixing of acid rock drainage with alkaline ash leachates-fate and immobilisation of trace elements. Water Air Soil Pollut 222:377-389. https://doi.org/10.1007/s11270-011-0831-8

Balintova M, Petrilakova A (2011) Study of pH influence on selective precipitation of heavy metals from acid mine drainage. Chem Eng Trans 25:345-350. https://doi.org/10.3303/CET1125058

Boulanger-Martel V, Bussière B, Côté J, Gagnon P (2017) Design, construction, and preliminary performance of an insulation cover with capillary barrier effects at Meadowbank mine, Nunavut. In: 70th Canadian Geotechnical Conference. Ottawa, Ontario, Canada, p 354

Cavusoglu I, Yilmaz E, Yilmaz AO (2021) Additivity effect on properties of cemented coal fly ash backfill containing water-reducing admixtures. Constr Build Mater 267:121021. https://doi.org/10.1016/j. conbuildmat.2020.121021

Galhardi JA, Bonotto DM (2016) Hydrogeochemical features of surface water and groundwater contaminated with acid mine drainage (AMD) in coal mining areas: a case study in southern Brazil. Environ Sci Pollut Res 23:18911-18927. https://doi.org/10.1007/ s11356-016-7077-3

Gitari MW, Petrik LF, Etchebers O, Key DL, Iwuoha E, Okujeni C (2006) Treatment of acid mine drainage with fly ash: removal of major contaminants and trace elements. J Environ Sci Heal Part A 41:1729-1747. https://doi.org/10.1080/10934520600754425
Gray NF (1996a) Field assessment of acid mine drainage contamination in surface and ground water. Environ Geol 27:358-361. https://doi. org/10.1007/BF00766705

Gray NF (1996b) Field assessment of acid mine drainage contamination in surface and ground water. Environ Geol 27:358-361. https://doi. org/10.1007/BF00766705

Gupta V, Pathak DK, Siddique S, Kumar R, Chaudhary S (2020) Study on the mineral phase characteristics of various Indian biomass and coal fly ash for its use in masonry construction products. Constr Build Mater 235:117413. https://doi.org/10.1016/j.conbuildmat. 2019.117413

Höglund LO, Herbert RB, Lövgren L, et al (2004) MiMi-performance assessment-main report: MiMi report 2003:3

IEA (2019a) Key world energy statistics 2019. International Energy Agency, Paris

IEA (2019b) Coal information: overview, 2019th edn. International Energy Agency, Paris

INAP (2014) International Network for Acid Prevention (INAP) global acid rock drainage (GARD) guide

Izquierdo M, Querol X (2012) Leaching behaviour of elements from coal combustion fly ash: an overview. Miner Trace Elem Coal 94:54-66. https://doi.org/10.1016/j.coal.2011.10.006

Jia Y, Hamberg R, Qureshi A, Mäkitalo M, Maurice C (2019) Variation of green liquor dregs from different pulp and paper mills for use in mine waste remediation. Environ Sci Pollut Res 26:31284-31300. https://doi.org/10.1007/s11356-019-06180-0

Jia Y, Maurice C, Öhlander B (2014) Effect of the alkaline industrial residues fly ash, green liquor dregs, and lime mud on mine tailings oxidation when used as covering material. Environ Earth Sci 72: 319-334. https://doi.org/10.1007/s12665-013-2953-3

Jouini M, Benzaazoua M, Neculita CM, Genty T (2020) Performances of stabilization/solidification process of acid mine drainage passive treatment residues: assessment of the environmental and mechanical behaviors. J Environ Manag 269:110764. https://doi.org/10.1016/j. jenvman.2020.110764

Kalonji Kabambi A, Bussière B, Demers I (2017) Hydrogeological behaviour of covers with capillary barrier effects made of mining materials. Geotech Geol Eng 35:1199-1220. https://doi.org/10.1007/ s10706-017-0174-3

Krauskopf KB, Bird DK (1995) Introduction to geochemistry. McGrawHill, New York

LCDC (2020) Quality of coal and reserves at Lakhra coal field. http:// lcdc.gov.pk/quality-of-coal/. Accessed 10 Jun 2020

Lessard F, Bussière B, Côté J, Benzaazoua M, Boulanger-Martel V, Marcoux L (2018) Integrated environmental management of pyrrhotite tailings at Raglan Mine: part 2 desulphurized tailings as cover material. J Clean Prod 186:883-893. https://doi.org/10.1016/j. jclepro.2018.03.132

Li A, Andruchow B, Wislesky I, Olson E (2011) Field testing of codisposal techniques for acid generating tailings and waste rock at cerro de maimón mine. Tailings and Mine Waste. Vancouver, In

Long SE, Martin TD (1991) METHOD 200.8 - determination of trace elements in waters and wastes by inductively coupled plasma-mass spectropemtry. Methods Determ Met Environ Samples EPA/600/4-: 84-122

Lottermoser B (2007) Mine wastes: characterization, treatment and environmental impacts. Springer Publisher, Heidelberg

Lyew D, Sheppard J (2001) Use of conductivity to monitor the treatment of acid mine drainage by sulphate-reducing bacteria. Water Res 35 : 2081-2086. https://doi.org/10.1016/S0043-1354(00)00473-5

Mäkitalo M, Mácsik J, Maurice C, Öhlander B (2015) Improving properties of sealing layers made of till by adding green liquor dregs to reduce oxidation of sulfidic mine waste. Geotech Geol Eng 33: 1047-1054. https://doi.org/10.1007/s10706-015-9886-4

Mäkitalo M, Stenman D, Ikumapayi F, Maurice C, Öhlander B (2016) An evaluation of using various admixtures of green liquor dregs, a 
residual product, as a sealing layer on reactive mine tailings. Mine Water Environ 35:283-293. https://doi.org/10.1007/s10230-0150340-x

Martin TD, Brockhoff CA, Creed JT, Long SE (1991) METHOD 200.7 determination of elements and trace elements in water and wastes by inductively coupled plasma-atomic emmission spectropemtry. Methods Determ Met Environ Samples EPA/600/4-:31-82

Martinello K, Oliveira MLS, Molossi FA, Ramos CG, Teixeira EC, Kautzmann RM, Silva LFO (2014) Direct identification of hazardous elements in ultra-fine and nanominerals from coal fly ash produced during diesel co-firing. Sci Total Environ 470-471:444-452. https://doi.org/10.1016/j.scitotenv.2013.10.007

Nason P, Alakangas L, Öhlander B (2013) Using sewage sludge as a sealing layer to remediate sulphidic mine tailings: a pilot-scale experiment, northern Sweden. Environ Earth Sci 70:3093-3105. https://doi.org/10.1007/s12665-013-2369-0

Parkhurst DL, Appelo CAJ (2013) Description of input and examples for PHREEQC version 3-a computer program for speciation, batchreaction, one-dimensional transport, and inverse geochemical calculations. In: Book 6, Modeling Techniques. U.S. Geological Survey, United States of America

Pérez-López R, Cama J, Miguel Nieto J, Ayora C, Saaltink MW (2009) Attenuation of pyrite oxidation with a fly ash pre-barrier: reactive transport modelling of column experiments. Appl Geochem 24: 1712-1723. https://doi.org/10.1016/j.apgeochem.2009.05.001

Pérez-López R, Nieto JM, de Almodóvar GR (2007) Utilization of fly ash to improve the quality of the acid mine drainage generated by oxidation of a sulphide-rich mining waste: column experiments. Chemosphere 67:1637-1646. https://doi.org/10.1016/j. chemosphere.2006.10.009

Pouliot S, Bussière B, Dagenais A-M, et al (2018) Evaluation of the use of sulphide paste rock as cover material in mine reclamation. In: Wolkersdorfer, Ch.; Sartz, L.; Weber, A.; Burgess, J.; Tremblay G (ed) 11th ICARD | IMWA | MWD Conference - "Risk to Opportunity." pp 559-564

Prasad B, Mortimer RJG (2011) Treatment of acid mine drainage using fly ash zeolite. Water Air Soil Pollut 218:667-679
Qureshi A, Jia Y, Maurice C, Öhlander B (2016a) Potential of fly ash for neutralisation of acid mine drainage. Environ Sci Pollut Res 23:112. https://doi.org/10.1007/s11356-016-6862-3

Qureshi A, Maurice C, Öhlander B (2016b) Potential of coal mine waste rock for generating acid mine drainage. J Geochemical Explor 160: 44-54. https://doi.org/10.1016/j.gexplo.2015.10.014

Qureshi A, Maurice C, Öhlander B (2019) Effects of the co-disposal of lignite fly ash and coal mine waste rocks on AMD and leachate quality. Environ Sci Pollut Res 26:4104-4115. https://doi.org/10. 1007/s11356-018-3896-8

Ritchie GSP (1989) The chemical behaviour of aluminium, hydrogen and manganese in acid soils. In: Robson AD (ed) Soil acidity and plant growth. Academic Press Sydney, pp 1-60

Sánchez España J (2007) The behavior of iron and aluminum in acid mine drainage: speciation, mineralogy, and environmental significance. In: Letcher TM (ed) Thermodynamics. Solubility and Environmental Issues. Elsevier, Amsterdam, pp 137-150

Shanmugan S, Deepak V, Nagaraj J, et al (2020) Enhancing the use of coal-fly ash in coarse aggregates concrete. In: Materials Today: Proceedings. Elsevier Ltd, pp 174-182

Siddiqui I (1999) Heavy metal studies in lakhra coal. University of Peshawar Pakistan

Villain L, Alakangas L, Öhlander B (2013) The effects of backfilling and sealing the waste rock on water quality at the Kimheden open-pit mine, northern Sweden. J Geochemical Explor 134:99-110. https:// doi.org/10.1016/j.gexplo.2013.08.003

Wei X, Viadero RC, Buzby KM (2005) Recovery of iron and aluminum from acid mine drainage by selective precipitation. Environ Eng Sci 22:745-755. https://doi.org/10.1089/ees.2005.22.745

Yao ZT, Ji XS, Sarker PK, Tang JH, Ge LQ, Xia MS, Xi YQ (2015) A comprehensive review on the applications of coal fly ash. EarthScience Rev 141:105-121

Publisher's note Springer Nature remains neutral with regard to jurisdictional claims in published maps and institutional affiliations. 